Campbell University School of Law

Scholarly Repository @ Campbell University School of Law

2015

\title{
Judicial Doctrine as Risk Regulation
}

Michael B. Kent Jr.

Campbell University School of Law, mkent@campbell.edu

Brannon P. Denning

Cumberland School of Law

Follow this and additional works at: https://scholarship.law.campbell.edu/fac_sw

\section{Recommended Citation}

Michael B. Kent Jr. \& Brannon P. Denning, Judicial Doctrine as Risk Regulation, 82 Tenn. L. Rev. 405 (2015).

Available at: https://scholarship.law.campbell.edu/fac_sw/106

This Article is brought to you for free and open access by the Faculty Scholarship at Scholarly Repository @ Campbell University School of Law. It has been accepted for inclusion in Scholarly Works by an authorized administrator of Scholarly Repository @ Campbell University School of Law. 


\title{
JUDICIAL DOCTRINE AS RISK REGULATION
}

\author{
BRANNON P. DENNING ${ }^{*}$ \& MICHAEL B. KENT, JR. ${ }^{*}$
}

Much of the literature on risk regulation concerns "first-order" risks—e.g., those addressed by environmental law or workplace safety rules. But scholars recently have suggested that risk regulation can provide a helpful framework for thinking about "second-order," or political, risks arising from allocations of power and institutional design. Although a few commentators have utilized this perspective to suggest connections between risk regulation and particular areas of constitutional law, in this essay we take a broader view. Building on the existing literature, we argue that the selection of constitutional decision rules is a judicial effort to regulate the political risk that government officials will violate constitutional principles.

After making the case that it is helpful to view judicial doctrinal formation as a species of political risk regulation, we discuss some implications of this risk regulation model and pose some questions for future research. We conclude that the risk regulation model reinforces the notion that the formation of doctrine is a temporally extended process, rather than a one-time event, and it provides a metric by which that doctrine can be evaluated. Additionally, the risk regulation model helps explain some of the more commonly critiqued features of constitutional law. Finally, the risk regulation model raises important questions that merit further investigation: (1) Should we trust judicial perceptions of and responses to political risk? (2) What influences risk assessment among judges, and are those influences (and resulting assessments) normatively defensible? (3) What connection, if any, exists between judicial risk assessment and the myriad doctrinal formulae employed by the Supreme Court?

I. INTRODUCTION 406

II. DECISION RULE CHOICE AND JUDICIAL REGULATION OF POLITICAL RISK

A. Regulation of First-Order Risks.

B. Political Risk Regulation

C. Doctrinal Design as Political Risk Regulation

III. IMPLICATIONS AND AN AGENDA FOR FUTURE RESEARCH University.

* Associate Dean and Professor, Cumberland School of Law, Samford

** Associate Professor of Law, Norman Adrian Wiggins School of Law, Campbell University. Many thanks to Ben Barton for helpful comments on an earlier draft. 
A. Implications

1. Decision Rule Choice is a Process, Not Event

2. Furnishes a Metric for Evaluating Doctrinal Rules.. 428

3. The Model's Explanatory Power 428

a. Explains Changes in Court's Agenda 430

b. Explains Inter-Doctrinal Variety............................ 433

c. Explains Intra-Doctrinal Inconsistency

B. Agenda for Future Research

IV. CONCLUSION

\section{INTRODUCTION}

As a number of scholars have pointed out, determining what the Constitution permits or prohibits through interpretation is ordinarily only the first step employed by the United States Supreme Court when it decides cases. This first step-where the Court derives from the Constitution what Mitchell Berman has termed "constitutional operative propositions"-is then followed by a second step where the Court implements those propositions through the development of "constitutional decision rules." 1 As Kermit Roosevelt notes, decision rules are what "the Supreme Court creates to take it from the grand language of the Constitution to the actual outcomes of particular cases." 2 These decision rules, which make up the warp and woof of ordinary constitutional law, are familiar to students. ${ }^{3}$ They are the multi-part tests and standards of review that Robert Nagel criticized as part and parcel of the "formulaic Constitution."4

1. Mitchell N. Berman, Constitutional Decision Rules, 90 VA. L. REV. 1, 9 (2004); see also Mitchell N. Berman, Aspirational Rights and the Two-Output Thesis, 119 HARV. L. REV. F. 220, 221 (2006).

2. KeRmit ROOSEVElt III, THE MYTH OF Judicial ACtivism: MAKING SENSE OF SUPREME COURT DECISIONS 19 (2006).

3. See RichaRd H. FAllon, JR., Implementing the CONSTitution 7-101 (2001). (cataloguing and analyzing the Court's use of seven types of doctrinal tests); see also LACKLAND H. BLOOM, JR., METHODS OF INTERPRETATION 205, 257-350 (2009) (defining doctrine as "the rules that are developed from prior cases, which at some point seem to assume a life quite independent of the cases from which the] rules arose and which are applied in subsequent cases with no consideration of the factual contexts out of which they initially arose," and discussing how doctrine is formed and changed by the Court).

4. See ROOSEVELT, supra note 2, at 19:

Read some Supreme Court opinions . . . Y You will encounter tiers of scrutiny, five-factor tests, requirements of congruence and proportionality, 
Richard Fallon has classified these decision rules; 5 other scholars have analyzed and critiqued decision rules developed in particular areas of constitutional law. ${ }^{6}$ Decision rules take many forms-rules, standards, suspect-content rules, balancing tests, and tiered scrutiny are merely a few of their more familiar iterations. Importantly, decision rules occupy various points along a spectrum running from near-total deference (consider the "classic" rational basis of economic substantive due process ${ }^{7}$ ) to a near-conclusive presumption of unconstitutionality (judicial review of prior restraints 8 and penalties for religious belief or nonbelief ${ }^{9}$ are two examples).

In an earlier article, we contributed to this literature by describing anti-evasion doctrines ("AEDs"). ${ }^{10}$ AEDs are decision rules that the Court creates and applies to fill gaps left by earlier decision rules, specifically gaps that allow form-over-substance evasion of those rules. ${ }^{11}$ In a second article, we discussed the Court's refusal to create AEDs and speculated about what motivates the Court to create them in some cases and not in others. ${ }^{2}$ That the Court is regularly called on to reassess the sufficiency of earlier

and undue burden analysis. You will find a host of bewildering distinctions, between content-based and content-neutral regulations of speech, between hard and soft money, between intentional discrimination and disparate impact. All these and more await new law students and citizens bold enough to venture into the work product of their nation's highest court.

See generally Robert F. Nagel, The Formulaic Constitution, 84 MICH. L. REV. 165 (1985).

5. FALLON, supra note 3, at 7-101.

6. For other contributions to this literature, see Brannon P. Denning \& Michael B. Kent, Jr., Anti-Evasion Doctrines in Constitutional Law, 2012 UTAH L. REV. 1773, 1775 n.6 [hereinafter Denning \& Kent, Anti-Evasion Doctrines].

7. See, e.g., Williamson v. Lee Optical Co., 348 U.S. 483, 488 (1955) ("The day is gone when this Court uses the Due Process Clause of the Fourteenth Amendment to strike down state laws, regulatory of business and industrial conditions, because they may be unwise, improvident, or out of harmony with a particular school of thought.").

8. Bantam Books, Inc. v. Sullivan, 372 U.S. 58, 70 (1963) ("Any system of prior restraints of expression comes to this Court bearing a heavy presumption against its constitutional validity.").

9. Torcaso v. Watkins, 367 U.S. 488, 495 (1961) (" $[N]$ either a State nor the Federal Government can constitutionally force a person to profess a belief or disbelief in any religion."').

10. Denning \& Kent, Anti-Evasion Doctrines, suprá note 6, at 1779.

11. Id.

12. Brannon P. Denning \& Michael B. Kent, Jr., Anti-Anti-Evasion in Constitutional Law, 41 FLA. ST. U. L. REV. 397 (2014) [hereinafter Denning \& Kent, Anti-Anti-Evasion]. 
decision rules, and sometimes supplements them in light of new threats to the principles they were supposed to implement, suggests that the creation and application of decision rules is a process rather than a one-time event. ${ }^{13}$

This process by which judges create doctrine, moreover, seems to us a species of risk regulation..$^{14}$ Risk regulation is the subject of an enormous literature. ${ }^{15}$ Much of that literature addresses risks to life and health posed by new or existing technologies and the efforts of government to ameliorate or mitigate those risks through regulation. But in addition to these "first-order risks"-i.e., those that arise from "unintended consequences of human action" or "the intended result of human action" or "the interaction between human action and the forces of nature" and that are addressed by environmental law, workplace safety rules, and the like-scholars recently have suggested that risk regulation can provide a helpful framework for thinking about "second-order" or "political" risks-i.e., those "that arise from the design of institutions, from the allocation of power across institutions, and from the selection of officials to staff institutions." 16 This framework posits that "constitutions and public law generally are best understood as devices for regulating and managing political risks." 17 As Adrian Vermeule put it recently: "[P]olitical risk regulation asks how institutions should be designed, how competences should be allocated, and how officials should be selected to produce the best attainable constitutional system."18 A few commentators have utilized this perspective to suggest connections between risk regulation and particular areas of constitutional law, ${ }^{19}$ but we are not aware of any work that has

13. Denning \& Kent, Anti-Evasion Doctrines, supra note 6, at 1814 .

14. Id.

15. For a sampling, see infra Part II.A and sources cited therein.

16. ADRIAN VERMEULE, THE CONSTITUTION OF RISK 3-4 (2014).

17. Id. at 2.

18. Adrian Vermeule, Introduction: Political Risk and Public Law, 4 J. LEGAL ANALYSIS 1 (2012) [hereinafter Vermeule, Political Risk].

19. See, e.g., VERMEULE, supra note 16 , at 29-45 (describing constitutional principles and interpretive techniques that exhibit features of the precautionary principle used to address health and safety risks); Jonathan Remy Nash, The Supreme Court and the Regulation of Risk in Criminal Law Enforcement, 92 B.U. L. REV. 171, 224 (2012) (criticizing "attempts by the Supreme Court to import paradigmatic risk analysis into the criminal law"); Mark Tushnet, The First Amendment and Political Risk, 4 J. LEGAL ANALYSIS 103, 105-06 (2012) (critiquing particular First Amendment decisions "by describing several cases in which the courts' assessment of the risk that speech causes harm seems mistaken, either because the courts seem to be mistaken in thinking that the legislature's estimates of the risk of harm are excessive ... or because the courts are insensitive to questions 
looked at judicial doctrine-creation generally through the lens of risk regulation. We do so here.

In this essay, we argue that the selection of decision ruleseither initially or subsequently (as in the case of AEDs)-should be understood as judicial efforts to regulate public risk, the public risk being violation of constitutional principles by government officials. The selection of decision rules strikes us as precisely the kind of second-order, retail-level political risk regulation that Vermeule describes. Constitutional principles often come framed at a relatively high level of generality - so high, in fact, that direct enforcement is usually difficult, if not impossible. ${ }^{20}$ The decision rules occupy the role of intermediating regulations that get applied to particular situations to resolve actual cases. ${ }^{21}$ The analogy here is to administrative agency personnel charged with designing regulations that address risks according to guidelines furnished in legislationusually at a comparably high level of generality. Unlike administrative regulations however, the decision rules developed and applied by the Court are not subject to executive branch or

about the distribution of harm.") (footnotes omitted). Though he did not use the vocabulary of risk regulation, Vincent Blasi's article The Pathological Perspective and the First Amendment, 85 CoLUM. L. REV. 449 (1985), makes a normative case that the Court ought to adopt something like the precautionary principle when it comes to the First Amendment. The Court's "overriding objective" in interpreting the First Amendment, he wrote,

should be to equip the first amendment to do maximum service in those historical periods when intolerance of unorthodox ideas is most prevalent and when governments are most able and most likely to stifle dissent systematically. The first amendment, in other words, should be targeted for the worst of times.

Id. at 449-50. Blasi then immediately suggested that other rules might obtain for different provisions of the Constitution. Id. at 450 "'Certain clauses-the equal protection and cruel and unusual punishment clauses, for example-may be designed, or at least most wisely interpreted, to serve the society primarily in periods of unusual idealism or cohesion.").

20. ROOSEVELT, supra note 2, at 18-19 (arguing that "the plain meaning [of the Constitution] does not get us all the way to a decision. The idealized opposite of judicial activism-what I call 'direct enforcement' of the Constitution-turns out to be a fantasy.").

21. Charles Fried, Saying What the LaW Is: The Constitution in the SUPREME COURT 3 (2004) ("Unmediated, fresh reference in contemporary disputes to the spare and distant text of the Constitution cannot possibly offer the regularity and rationality which is the indispensable characteristic of a government of law. The Constitution's text must be mediated by doctrine before it can yield decision."). 
congressional oversight and correction if the regulators misapprehend the risk by over- or under-regulating it. ${ }^{22}$

Our argument proceeds as follows. Part II discusses theoretical models of risk regulation generally, describes recent scholarship applying those models to the regulation of political risk specifically, and situates doctrinal formation in the latter conversation. Part III canvasses the implications of our theories for constitutional law more broadly and suggests some questions for future research.

Conceiving the choice of constitutional doctrine as risk regulation strengthens our belief that the formation of doctrine is a temporally extended process. If doctrine is a manifestation of the Justices' perceptions of political risk, then changing doctrine suggests that those perceptions of risk change from time to time. This fact, in turn, can explain several features of the Court's constitutional jurisprudence. It explains why the Court's agenda has changed over time-for example, shifting from the protection of property rights to civil liberties in the 1940 s or the revival in judicially-enforced federalism during the Rehnquist Court. The risk regulation model of doctrine can also explain doctrinal fluidity. Changes in perceptions of risk can cause the Court to alter the level of judicial scrutiny in particular areas, substituting a deferential standard of review for a more searching one or vice versa. The diversity of the Court's decision rules formulae-the different standards of review, tiered scrutiny, per se rules of illegitimacy, and the like-may all be put down to the Court's varied perceptions of risk to particular constitutional principles. In addition, variances in risk perception may explain intradoctrinal variety as well. The use by the Court of rational basis with "bite," for example, may have more to do with a perceived increase in risk to constitutional principle than with willful mendacity on the Court's part.

If we are correct, a host of questions arise. How do Justices assess these risks? Are their perceptions defensible, or are they products of various cognitive biases that infect so much of human thinking elsewhere? Are there dominant factors that play a role in either risk perception or in the means chosen to meet the perceived risk? Are there mechanisms available to the Justices to test their assumptions, perhaps helping to de-bias their decisions? Are there institutional reforms that could help? What about the Court's specific responses to risk? Are those responses optimal ones, or do

22. VERMEULE, supra note 16 , at 10-11 (presenting "precautionary constitutionalism" and "optimizing constitutionalism" as opposing points on a riskregulation spectrum); see also Lawrence Gene Sager, Fair Measure: The Legal Status of Underenforced Constitutional Norms, 91 HARV. L. REV. 1212 (1978) (discussing the underenforcement of constitutional principles by courts). 
they instead unduly over- or under-enforce particular constitutional principles? How, precisely, do particular decision rules function as risk regulation? We raise these questions in Part III but do not attempt to resolve all of them, leaving resolution of those questions for future work.

\section{DeCision Rule Choice AND Judicial REgulation of POLITICAL RISK}

In this Part we make our case that judicial design of doctrine, including both the initial choice and supplementing of decision rules to implement constitutional principles, is a form of political risk regulation undertaken by the Supreme Court. In doing so, we first briefly describe some leading theories of first-order risk regulation, including the precautionary principle, cost-benefit analysis, and cultural risk cognition. We then look at the application of risk regulation to second-order political risks. Just as constitutional provisions and interpretive rules attempt to regulate risk at the wholesale level by anticipating and preventing harms from becoming manifest, we think that courts-the Supreme Court in particularemploy retail level decision rules to guard against similar risks in a way that is hinted at in the existing literature but not fully explored.

\section{A. Regulation of First-Order Risks}

As noted above, risk regulation is the subject of a vast literature in a variety of fields, much of which concerns first-order risks associated with environmental protection, food and drug regulation, occupational safety, and related areas of public policy.23 In addressing these types of risks, regulators must focus on a number of complex issues. A "somewhat stylized summary of how environmental law responds to risk," for example, emphasizes the following questions: "(1) Is there any risk? (2) Is the showing of risk sufficient to justify governmental action? (3) What about the riskrisk tradeoffs?24 (4) Who is best positioned to answer these questions?"25

23. VERMEULE, supra note 16 , at 3.

24. The phrase "risk-risk tradeoffs" refers to the fact that regulation itself may give rise to risks that minimize or undermine the purpose for which the regulation is being proposed. See Nash, supra note 19, at 195-96 ("Risk-risk analysis calls upon regulators to balance the risks that a proposed regulation will reduce against the risks to which regulation itself may give rise."); see also Cass R. Sunstein, Beyond the Precautionary Principle, 151 U. PA. L. REV. 1003, 1024 (2003) [hereinafter Sunstein, Precautionary Principle] (discussing the problem of "substitute risks, in the form of 
Although on the surface these inquiries appear to be fairly straightforward, a foundational problem in regulating first-order risks is how to respond to threats in the absence of complete information. What if regulators are uncertain about the magnitude of danger that might accompany a particular action or even whether the danger really exists in the first place? To account for the varying levels of knowledge that regulators possess when making decisions, scholars have distinguished among conditions of risk, uncertainty, and ignorance. Situations involving "risk," from a technical standpoint, are those in which decision-makers know both the possible outcomes that may result from an activity and the probabilities associated with those outcomes. ${ }^{26}$ In circumstances involving "uncertainty," however, the decision-makers can determine only the possible outcomes; the probabilities that those outcomes will occur remain unquantifiable. ${ }^{27}$ Finally, some situations call for decisions to be made where neither the possible outcomes nor their probabilities can be established, a condition known in the literature as "ignorance." 28 All of these situations fall under the general heading of risk. ${ }^{29}$

How best to deal with these various information gaps is a subject of substantial importance in the literature on first-order risk regulation. Especially significant is how to regulate in conditions of uncertainty or ignorance. Many first-order risks-those associated with environmental policy, for example-present "complex technical and economic issues" about which "lawmakers rarely have anything approaching perfect knowledge."30 This dearth of information is central to a debate between proponents of the two leading models for

hazards that materialize, or are increased, as a result of regulation").

25. Nash, supra note 19 , at 192 .

26. The Precautionary Principle in the 20Th Century: Late lessons FROM EARLY WARNINGS 188 (Poul Harremoës et al., eds., 2002); see also Aaron Wildavsky, The Political Economy of Efficiency: Cost-Benefit Analysis, Systems Analysis, and Program Budgeting, 26 PUB. ADMIN. REV. 292, 296 (1966) (defining "risk" as situation "where the precise outcome cannot be predicted but a probability distribution can be specified").

27. The Precuationary PRINCIPLe IN THE 20Th CENTURY, supra note 26, at 188.

28. Id.

29. See VERMEULE, supra note 16, at 6 ("The term has a colloquial sense that includes . . . well-defined decision-theoretic concepts such as risk, uncertainty, and ignorance.").

30. James SAlzman \& Barton H. ThOMPSON, JR., ENVIRONMENTAL LAW AND PoLICY 14 (3d ed. 2010). 
assessing and managing risk - the precautionary principle and costbenefit analysis. ${ }^{31}$

"[F] ast becoming a staple of regulatory policy,"32 the precautionary principle has been prominent in the field of international environmental law $^{33}$ and is reflected in various strands of American law, as well. ${ }^{34}$ Attempts to discuss the principle are made difficult, however, by the absence of agreement on what it actually means or demands. ${ }^{35}$ Indeed, one account has identified nineteen different versions of the principle. ${ }^{36}$ It is useful, therefore, to think of a continuum of various precautionary principles, ranging from weak to strong iterations. ${ }^{37}$ Weak versions of the principle typically hold that an activity can be regulated despite a lack of conclusive evidence regarding the nature or extent of the risk posed by that activity. ${ }^{38}$ Stronger versions suggest an anticipatory approach to risk management, favoring regulation in the face of uncertainty and shifting the burden of proof to the proponent of the putatively harmful activity to show that it should not be regulated. ${ }^{39}$ Especially in its strong forms, the precautionary principle is marked by its prophylactic tendencies: "The Principle encourages conducting . . risk assessment, where possible, on an ex ante, premarket basis, rather than in a reactive posture in response to harm that has already occurred." 40

Often juxtaposed against the precautionary principle is some form of cost-benefit analysis. Here, too, discussions "are hampered by lack of consistency in the use of terms." 41 As explained by

31. See, e.g., Gregory N. Mandel \& James Thuo Gathii, Cost-Benefit Analysis Versus The Precautionary Principle: Beyond Cass Sunstein's Laws of Fear, 2006 U. ILL. L. REV. 1037, 1038 (reviewing CASS SUNSTEIN, LAWS OF FEAR: BEYOND THE PRECAUTIONARY PRINCIPLE (2005)) (describing cost-benefit analysis and precautionary principle as "paramount" paradigms for risk regulation).

32. Sunstein, Precautionary Principle, supra note 24, at 1005.

33. SALZMAN \& THOMPSON, supra note 30 , at 17.

34. See, e.g., Noah M. Sachs, Rescuing the Strong. Precautionary Principle From Its Critics, 2011 U. ILL. L. REV. 1285, 1307-10 (noting examples).

35. Id. at 1292 ("Precaution in risk regulation is controversial, in part, because of a lack of consensus on what precaution means."); Sunstein, Precautionary Principle, supra note 24, at 1011 ("There are numerous definitions [of the precautionary principle], and they are not compatible with one another.").

36. See Sachs, supra note 34, at 1292 n.28 (citing Per Sandin, Dimensions of the Precautionary Principle, 5 HUM. \& ECOLOGICAL RISK ASSESSMENT 899 (1999)).

37. Sunstein, Precautionary Principle, supra note 24, at 1011-12.

38. Id. at 1012; see also Sachs, supra note 34, at 1292.

39. Sachs, supra note 34 , at 1288 \& n. 12 .

40. Id. at 1298.

41. Matthew D. Adler \& Eric A. Posner, Rethinking Cost-Benefit Analysis, 109 
Professor Vermeule: 'Cost-benefit analysis' is a protean term that can be used to encompass everything from informal consequentialism-Charles Darwin's list of the pros and cons of marriage - to a formal, fully monetized analysis of compensating variations based on willingness to pay and accept." 42 Used in its less formal sense, cost-benefit analysis serves primarily as "an invitation to identify the advantages and disadvantages of regulation," 43 often by widening the focus so that all relevant risks and alternativesincluding those resulting from regulatory action itself-are placed in consideration. ${ }^{44}$

In addition to the precautionary principle and cost-benefit analysis, a third (and growing) school of thought emphasizes the role of cultural cognition in assessing and managing first-order risks. Scholars who advance this theory use the phrase "cultural cognition" to "refer to the psychological disposition of persons to conform their factual beliefs about the instrumental efficacy (or perversity) of law to their cultural evaluations of the activities subject to regulation." 45 Put differently, people perceive certain activities as risky or notand correspondingly view public policies designed to deal with those risks as beneficial or not-based largely on their preexisting cultural commitments and worldviews. ${ }^{46}$ If correct, this theory posits that there is more to conflicts over risk regulation than gaps in the available information. As an initial matter, the argument goes, even where individuals are presented with sound information, they nonetheless evaluate that information in ways that reinforce their own cultural predispositions. 47 Secondly, and perhaps more importantly, individuals tend to obtain information from sources

YALE L.J. 165, 176 (1999); see also Cass R. Sunstein, Cognition and Cost-Benefit Analysis, 29 J. LEGAL STUD. 1059, 1060 (2000) [hereinafter Sunstein, Cognition] ("[M] uch of the controversy over cost-benefit analysis stems from the difficulty of specifying, with particularity, what that form of analysis entails.").

42. VERMEULE, supra note 16 , at 79 (footnotes omitted).

43. Sunstein, Cognition, supra note 41, at 1089.

44. See Sunstein, Precautionary Principle, supra note 24, at 1056-57 (advocating an approach that "would acknowledge that a wide variety of adverse effects may come from inaction, regulation, and everything in between"); see also Sachs, supra note 34, at 1306-07 (discussing cost-benefit approaches described by certain scholars as enabling regulators "to assess and compare the risks that would be created by different decision-making paths").

45. Dan M. Kahan \& Donald Braman, Cultural Cognition and Public Policy, 24 YALE L. \& POL'Y REV. 149, 151-52 (2006).

46. See id. at 154 ("[I] ndividuals select certain risks for attention and disregard others in a way that reflects and reinforces the particular worldviews to which they adhere.").

47. Id. at 151 . 
they trust, meaning that they rely on experts who share their worldviews and whose analyses often suffer from the same cultural biases. ${ }^{48}$

\section{B. Political Risk Regulation}

Although the foregoing theories were developed to manage environmental and technological threats to life and health, risk regulation analysis need not be confined to such first-order risks. Rather, as Professor Vermeule recently pointed out, these theories may also be applied productively to "second-order risks [arising] from the design of institutions, from the allocation of power across institutions to make first-order decisions, and from the selection of officials to staff institutions." 49 This section examines how Vermeule cashes out that observation by describing precautionary principles that occur both at the wholesale level of constitutional design and general interpretive principles, as well as at the retail interpretive level. ${ }^{50}$ Additionally, Vermeule describes (and supports) the "mature position" of second-order risk regulation, which is "structurally parallel" to the informal cost-benefit approaches contrasted against the precautionary principle in the first-order context. ${ }^{51}$

Vermeule begins his discussion by cataloguing examples in which versions of the precautionary principle recur in both constitutional history and constitutional law. The Anti-federalists, for example, feared that every delegation of power to government carried with it the seeds of tyranny and so based their opposition to a novel scheme of governance like the Constitution on the risk that such tyranny would come to pass. ${ }^{52}$ In this way, they "offered a precautionary master principle of constitutional design," dismissing niceties over the probability that such harm would occur and, instead, "aiming to preclude even the possibility that constitutional power would be abused."53 From such wholesale precautionary

48. Id. at 155-56; see also Dan M. Kahan, et al., Fear of Democracy: A Cultural Evaluation of Sunstein on Risk, 119 HARV. L. REV. 1071, 1094 (2006) (reviewing CASs SUnstein, LaWs of FEAR: BEYOND the PRECAUTIONARY PRINCIPLE (2005)) ("Like members of the general public, experts are inclined to form attitudes toward risk that best express their cultural vision.").

49. VERMEULE, supra note 16 , at 3-4.

50. Id. at $\mathbf{2 9 - 4 5 .}$

51. Id. at 77 .

52. Id. at 30 .

53. Id.; see also id. (discussing Hume's "knavery principle"-the idea that government should be designed upon the presumption that all men are knaves, thus incorporating checks and balances to restrain their baser motivations). 
notions, Vermeule then moves to a number of "retail principles of constitutional design" that likewise embodied some version of the precautionary principle. ${ }^{54}$ The unitary executive, ${ }^{55}$ separation of powers, 56 limits on the creation and maintenance of standing armies, ${ }^{57}$ and arguments favoring a bill of rights ${ }^{58}$ were defended and criticized on "explicitly precautionary grounds." 59

Rules of interpretation too, often reflect precautionary concerns at both wholesale and retail levels. Interpretive canons "urging that the constitution be 'strictly' or 'narrowly' construed to prevent political risks" are one example of wholesale precaution. ${ }^{60}$ Vermeule shows that these canons have been employed both with regard to federalism principles and in cases involving individual rights. ${ }^{61}$ Another example is provided by arguments favoring judicial review, which is said to offer valuable precautions "against an uncertain propensity to rights-violations by legislative and executive actors" by "add[ing] another veto-point to the lawmaking system."62

Of particular interest is Vermuele's discussion of retail-level interpretive principles. Though he does not frame his discussion, as we do here, in terms of doctrinal formation generally, he does observe that particular cases announce decision rules that incorporate precautionary principles. He cites, as one example, Chief Justice Marshall's bright-line rule prohibiting state taxation of federal instrumentalities in McCulloch v. Maryland.63 "Marshall argued that an expansive construction of state taxing power" endangered the existence of federal instrumentalities "because "the power to tax involves the power to destroy."'64 Precautionary arguments are particularly common, he argues, in First Amendment jurisprudence, citing as an example Vincent Blasi's "pathological" approach to the First Amendment that "urges judges to devise free speech doctrine by taking a 'pathological perspective', in which constitutional rules are geared to preventing the worst-case

54. Id.

55. Id. at 31 .

56. Id. at 31-32.

57. Id. at 32 .

58. Id. at $32-33$.

59. Id. at 31 .

60. Id. at 34 .

61. Id. at 35-36.

62. Id. at 36 .

63. 17 U.S. 316 (1819); VERMEULE, supra note 16 , at 37 .

64. VERMEULE, supra note 16 , at 37. 
scenario-abuses targeted at the speech of political minorities, dissenters, or opponents of the regime."65

Far from being an advocate for precautionary principles, Vermeule notes that they are vulnerable to various counterarguments-mainly that their costs are too high relative to the probability of the risk they guard against or that they actually increase the likelihood that the harm will come about.66 While precautionary principles, at least in their stronger versions, call for maximal protections against risk, Vermeule argues that constitutional designers and interpreters would do better to pursue optimal protections by adopting the so-called "mature position." Like some versions of the cost-benefit approach to first-order risk analysis, this model asks managers of second-order risks to "take optimal precautions, according to a calculus that weighs all relevant risks of action and inaction."67

We first encountered Professor Vermeule's work on these issues in the course of our earlier effort on anti-evasion doctrines. ${ }^{68} \mathrm{We}$ wondered whether AEDs were valuable enough to offset their costs, which included the introduction of doctrinal complexity and elevated decision costs, among others. ${ }^{69}$ Vermeule's work encouraged us to see AEDs as part of a judicial attempt to achieve the mature position by aiming for optimal enforcement of constitutional principles. ${ }^{70}$ AEDs permit courts to revisit a particular area of constitutional law and adjust doctrine in light of subsequent emergent risks-they furnish a calibrated ex post remedy to risk, as opposed to a maximal ex ante one. ${ }^{71}$ Relatedly, the existence of AEDs provides evidence that, in designing constitutional doctrine, the Court operates at varying levels of knowledge concerning the dangers presented by the challenged activity. As we explained in our previous article, "the Court sets initial decision rules based on the relevant information

65. Id. at 41 (footnote omitted). Other precautionary principles he discusses include due process rights to impartial tribunals, $i d$. at 43-49; the reasonable doubt rule, $i d$. at 44-45; and prophylactic rules like the Miranda warnings, id. at 45.

66. See id. at 54 (sketching the counterarguments); id. at 54-76 (discussing the precautionary design and interpretive elements in light of the counterarguments).

67. Id. at 52.

68. Denning \& Kent, Anti-Evasion Doctrines, supra note 6.

69. Id. at 1804-13 (discussing trade-offs).

70. Id. at 1813 ("Despite these tradeoffs, we believe that AEDs are, on balance, valuable in constitutional law [because they] embody what Professor Hirchman termed 'the mature position.").

71. VERMEULE, supra note 16 , at 72 ("[A]nother argument against precautions is that ex ante safeguards are unnecessary in light of the availability of ex post remedies...."). 
available to it and then revises and supplements those rules based on risk considerations that subsequently arise."72 In other words, just like first-order risk managers, the Court often acts in contexts of "uncertainty" and "ignorance," crafting (and re-crafting) decision rules to match the different levels of knowledge it has at different points in time. ${ }^{73}$

In the next section, we make a fuller case for the aptness and benefits of viewing this process-i.e., the process by which judges create doctrine through the choice and use of decision rules-as a species of political risk regulation. Our contribution to the discussion began by Vermeule and others is unique because we adopt here a wide-angle view, one that moves beyond particular responses to constitutional risk ${ }^{74}$ or the Court's performance as risk regulator in specific areas. ${ }^{75}$ The addition of Berman's two-output thesis, moreover, makes explicit what is at best implicit in other treatments of judicial risk regulation: that the decision rules themselves reflect judicial responses to perceived risk. To be sure, questions about judicial risk regulation abound, and we will identify some of those in Part III. Here, however, we simply want to explore the contours of judicial risk regulation.

\section{Doctrinal Design as Political Risk Regulation}

As the foregoing discussion demonstrates, the idea of "risk regulation" can apply as equally to constitutions and judicial pronouncements targeting second-order risks as it does to administrative regulations designed to address first-order risks. In fact, the assessment and management of political risk stretches back further into our history than its more contemporary cousin. In this section, we situate the choice of decision rules by courts, the Supreme Court in particular, into this tradition, arguing that such choices should be understood and studied as a particular type of political risk regulation. Ample evidence exists in the Court's own jurisprudence that the Justices have "often spoken the prose of risk

72. Denning \& Kent, Anti-Evasion Doctrines, supra note 6, at 1815.

73. See id. (suggesting that AEDs and process by which they are created enables Court, over time, to reach "more balanced risk assessment" as new information is made known).

74. See VERMEULE, supra note 16 (critiquing precautionary principles in constitutional law).

75. See Nash, supra note 19 (discussing the Supreme Court's risk analysis in criminal law); Tushnet, supra note 19 (discussing First Amendment doctrine through lens of risk regulation). 
regulation,"76 whether or not they were conscious of it. 77 Indeed, one can recognize examples of both precautionary and cost-benefit approaches to perceived risks in the different decision rules implemented by the Court.

We earlier observed that decision rules occupy points along a deference spectrum. ${ }^{78}$ The transition from more to less deference reflects a corresponding rise in the perceived level of risk to constitutional principle by official action. At one end of the spectrum, where the perceived risks are low, the Court takes a very deferential view that presumes official action comports with the Constitution. ${ }^{79}$ As risk perception rises, the Court relaxes its presumption of constitutionality and demands more evidence from the government that its action either will not trench on constitutional principles, or that the violation of constitutional principle is necessary to avoid or reduce the risk of some other harm that the law seeks to prevent or mitigate. In some cases, the burden on government is heavy indeed, approaching some strong version of the precautionary principle described above. 80

Strict scrutiny, for example, is probably the closest doctrinal analogue to a generic precautionary principle we have in constitutional law. Under the "modern test ... legislation will be upheld against constitutional challenge only if 'necessary' or 'narrowly tailored' to promote a 'compelling' governmental interest." 1 As Professor Fallon has documented, the test emerged in the 1960 s, making "nearly simultaneous appearances in multiple corners of constitutional law." 82 In his telling, strict scrutiny fit the bill as a "generic constitutional test capable of broad application" to "protect 'preferred' or fundamental rights that were too important to

76. Vermeule, Political Risk, supra note 18, at 2.

77. See also Tushnet, supra note 19, at 103, 104 (observing that "free speech doctrine [is] a response to risk"; and specifically, "First Amendment doctrine is at its core about the correct response to the fact that speech can increase the risk of social harm.").

78. Supra notes 7-9 and accompanying text.

79. See, e.g., Usery v. Turner Elkhorn Mining Co., 428 U.S. 1, 15 (1976) (" $[L]$ egislative Acts adjusting the burdens and benefits of economic life come to the Court with a presumption of constitutionality ....").

80. Supra notes 8-9 and accompanying text; see also Bantam Books, Inc. v. Sullivan, 372 U.S. 58, 70 (1963) ("Any system of prior restraints of expression comes to this Court bearing a heavy presumption against its constitutional validity.").

81. Richard H. Fallon, Jr., Strict Judicial Scrutiny, 54 UCLA L. REV. 1267, 1268 (2007).

82. Id. at 1270 . 
be enforced by a rational basis test, but that the Supreme Court could not reasonably define as wholly categorical or unyielding." 83

To put it another way, strict scrutiny developed as a response to the Justices' perceptions that governmental actions posed inordinately high risks to certain constitutional principles. We analogize strict scrutiny to the precautionary principle because $i^{84}$ shifts the burden of proof to the proponent (government) of the potentially harmful activity (law or regulation) to demonstrate that it is "safe" (i.e., poses no danger to the constitutional principle the standard of review protects).

By contrast, in the classic form of rational basis review, the Court demonstrates near-total deference to government officials, as it recently confirmed in the context of an Equal Protection Clause challenge to a municipal financing scheme.85 Writing for the majority, Justice Breyer described rational basis review in the following terms:

This Court has long held that "a classification neither involving fundamental rights nor proceeding along suspect lines ... cannot run afoul of the Equal Protection Clause if there is a rational relationship between the disparity of treatment and some legitimate governmental purpose." We have made clear in analogous contexts that, where "ordinary commercial transactions" are at issue, rational basis review requires deference to reasonable underlying legislative judgments. And we have repeatedly pointed out that "[1]egislatures have especially broad latitude in creating classifications and distinctions in tax statutes." 86

The Court's application of rational basis review thus suggests that it perceives the risks involved to be markedly different from those present in cases applying strict scrutiny. Where rational basis forms the standard of review, the Court implicitly concludes either that the risks to constitutional principle are minimal or that judicial involvement generates other risks that counsel abstinence (or both). That the Court undertakes this tacit weighing of risks, including those that may accompany its own action or inaction, hints at the

83. Id.

84. Or at least one version of strict scrutiny does this. We return to this point below. See infra notes 103-104 and accompanying. text.

85. See Amour v. City of Indianapolis, 132 S. Ct. 2073, 2079-82 (2012) (upholding distinctions made in financing arrangement under rational basis scrutiny).

86. Id. at $2079-80$ (internal citations omitted). 
type of informal cost-benefit analysis described by some scholars in the context of first-order risks.

The cost-benefit approach is even better reflected in some of the Court's other tests. In between strict scrutiny and rational basis, for example, lies intermediate scrutiny, in which "laws will be upheld so long as they serve some sort of a significant/substantial/important governmental interest and are reasonably well tailored to that purpose (i.e., not unreasonably overbroad)." 87 Or consider the forms of interest balancing that various Justices have endorsed over the years. Justice Marshall, for example, rejected tiered scrutiny in equal protection cases in favor of a sliding scale in which judicial scrutiny "var[ied] with 'the constitutional and societal importance of the interest adversely affected and the recognized invidiousness of the basis upon which the particular classification is drawn." 88 Justice Breyer has urged something similar in reviewing Second Amendment challenges to gun control laws. In his Heller dissent, Justice Breyer argued that the right of private persons to possess handguns for self-defense ought to be weighed against the possibility that such protections could endanger public safety by increasing gun crime. ${ }^{89}$ Finally, the Court's regulatory takings jurisprudence has long centered around "essentially ad hoc, factual inquiries designed to allow careful examination and weighing of all the relevant circumstances." 90 These tests tend to resemble cost-benefit approaches to risk.

In addition to the Justices themselves, those attempting to comprehend and explain constitutional doctrine also speak "the prose of risk regulation."91 A look at recent, sophisticated treatments of constitutional doctrine shows that, consciously or not, scholars frequently employ risk regulation concepts when seeking to understand the Court's decision rules and the rationales that underlie them. Professor Fallon's article on strict scrutiny, for example, provides the following description (reminiscent of risk

87. Ashutosh Bhagwat, The Test that Ate Everything: Intermediate Scrutiny in First Amendment Jurisprudence, 2007 U. ILL. L. REV. 783, 801 (summarizing survey of various applications of intermediate scrutiny in free speech cases).

88. City of Cleburne v. Cleburne Living Ctr., Inc., 473 U.S. 432, 460 (1985) (Marshall, J., concurring in part and dissenting in part) (quoting San Antonio Indep. Sch. Dist. v. Rodriguez, 411 U.S. 1, 99 (1973) (Marshall, J., dissenting)).

89. District of Columbia v. Heller, 554 U.S. 570, 682 (2008) (Breyer, J., dissenting).

90. Tahoe-Sierra Preservation Council, Inc. v. Tahoe Regl Planning Agency, 535 U.S. 302, 322 (2002) (internal quotations and citations omitted).

91. Supra note 76 and accompanying text. 
analysis) of how the "narrow tailoring" and "compelling interest" prongs of strict scrutiny interact:

[T] he effort to identify compelling interests and to determine the adequacy of regulatory tailoring is likely to involve fluid, two-way traffic in which assessments of ends and means occur simultaneously-at least in cases in which challenged governmental regulations, viewed realistically, will at best merely reduce risks or incidents of harm more or less effectively than would other regulations. ... The Court must determine whether infringements of constitutional rights, which can be more or less grievous, can be justified in view of the benefits likely to be achieved, the scope of infringement of protected freedoms, and the available alternatives. ${ }^{92}$

Like Professor Fallon, Peter Rubin has discussed the Court's use of strict scrutiny in terms of "costs," "risks," and "harms." 93 When considering the use of race in drawing electoral districts, Professor Rubin argues, a court ought first to "identify] which of the possible risks and harms associated with the government's use of race are present" and then "assess whether the costs that in fact attend the use of race .... are justified by any sufficiently strong legislative purposes."94 After considering the availability of race-neutral alternatives, "[a reviewing court] would have to consider whether ... the use of race is sufficiently harmful that a polity seeking to achieve these particular purposes should be required to bear whatever costs are attendant upon using such alternatives." 95

In her work on the First Amendment, Leslie Kendrick has similarly explored, in risk regulation terms, the scope of and justifications for the Court's decision rules in that area. For example, Professor Kendrick argues that the Court grounds its strict review of facial classifications of expression on the perceived risk that such classifications can easily mask an illicit or impermissible purpose

92. Fallon, supra note 81 , at 1333 (emphasis added); see also id. at 1331 ("[I]t ... seems impossible to think sensibly about compelling governmental interests and the narrow tailoring requirement as if they were sequentially isolated components of a bifurcated two-step inquiry .... In a practical sense, the dispositive, proportionality-like question becomes whether a particular, incremental reduction in risk justifies a particular infringement of protected rights in light of other reasonably available, more or less costly and more or less effective, alternatives.").

93. Peter J. Rubin, Reconnecting Doctrine and Purpose: A Comprehensive Approach to Strict Scrutiny After Adarand and Shaw, 149 U. PA. L. REv. 1, 9 (2000).

94. Id. at 123.

95. Id. 
and are thus deserving of precautionary treatment.96 Additionally, Professor Kendrick describes the Court's efforts to curb chilling effects on speech in terms of cost-benefit analysis:

[T]he identification of a chilling effect [first] implies a judgment that a given legal rule will overdeter protected speech as compared with its deterrence of unprotected speech and furtherance of other legitimate governmental interests. In essence, the court performs a type of cost-benefit analysis reminiscent of the Hand formula, in which it compares the benefits of a rule against the probability that protected speech will be chilled, with the protected speech being given appropriate weight as an affirmative and preferred value. Second, to arrive at a remedy, the court must consider the cost-benefit profiles of possible alternative rules and select the one that provides the optimal balance of reducing chilling and still furthering legitimate goals. .7

In conducting these evaluations, Professor Kendrick further notes that courts are often confronted with a host of information gaps about the law's deterrent effect, the value of the protected speech, and the probability of actual chilling. ${ }^{98}$ Thus, when courts seek to assess and manage the political risks associated with chilling speech, they operate in circumstances similar to those of "uncertainty" and "ignorance" in the first-order context.

Our own work, as well, contains hints of a risk-regulation approach to different areas. Denning has argued that the dormant Commerce Clause doctrine's decision rules should guard against the

96. See Leslie Kendrick, Content Discrimination Revisited, 98 VA. L. REV. 231, 253 (2012) ("For example, a categorical rule against facial discrimination on the basis of certain classifications may reflect the position that even the appearance of a suspect purpose is suspicious."); id. at 264 (commenting, about Minneapolis Star \& Tribune Co. v. Minn. Comm'r of Rev., 460 U.S. 575 (1983), that though "the Court held that evidence of invidious legislative intent was not necessary to render the law suspect, its reason appeared to be that facial discrimination against the press presents such a high risk of invidious intent that it is disallowed even when no evidence of such intent exists."); $i d$. at 265 ("Minneapolis Star thus suggests that a long historical association with suppression is sufficient to render a communicationbased classification facially suspect."); id. at 275 (on content-based rules: "One explanation for this rule is that subject-matter and viewpoint classifications have such a high probability of concealing an illicit purpose that one may confidently infer such a purpose from the fact of the classification.") (footnote omitted).

97. Leslie Kendrick, Speech, Intent, and the Chilling Effect, 54 WM. \& MARY L. REV. 1633, 1682 (2013).

98. Id. at $1682-83$. 
risks to political union attending commercial friction among states. ${ }^{99}$ In particular, he concluded that anti-discrimination rules best served this function, as opposed to the balancing of benefits and burdens to commerce that, if applied rigorously, would likely overprotect interstate commerce. 100 Kent has described the remedial system applied by the Court in takings cases-an insistence that regulatory takings be compensated rather than prohibited-as striking a balance between the risks posed to private property by governmental action, on the one hand, and the risks posed to the general welfare by individual holdouts, on the other. ${ }^{101}$ Finally, Kent has explained the heightened scrutiny the Court applies to land use exactions in terms of the political risks likely to attend them, and he has argued that monetary exactions in the land use context pose many of these same risks. ${ }^{102}$

The foregoing examples suffice to demonstrate that many of the doctrinal formulae employed by the Court-tiered scrutiny, First Amendment tests, the dormant Commerce Clause doctrine, takings jurisprudence, etc.-can be generally understood as judicial attempts to manage or regulate perceived risks that pose varying levels of danger to the specific constitutional values or principles the decision rules constituting the doctrine were designed to implement.

At the same time, specific applications of the same formulae in different contexts also seem to vary according to shifting risk perceptions among the Justices. In his article on strict scrutiny for example, Professor Fallon identified "three distinguishable versions of strict judicial scrutiny, all conducted pursuant to the same form of words." 103

One stringent version allows infringements of constitutional rights only to avert catastrophic or nearly catastrophic harms. Another, which views legislation as appropriately suspect when likely to reflect constitutionally forbidden purposes, aims at "smoking out" illicit governmental motives. A third version of strict scrutiny, partly belying the test's name, is not terribly strict at all and amounts to little more

99. Brannon P. Denning, Reconstructing the Dormant Commerce Clause Doctrine, 50 WM. \& MARY L. REV. 417, 484-85 (2008).

100. Id. at 493-94.

101. Michael B. Kent, Jr., Construing the Canon: An Exegesis of Regulatory Takings Jurisprudence After Lingle v. Chevron, '16 N.Y.U. ENVTL. L.J. 63, 87-88 (2008).

102. Michael B. Kent, Jr., Theoretical Tension and Doctrinal Discord: Analyzing Development Impact Fees as Takings, 51 WM. \& MARY L. REV. 1833, 1853-59 (2010).

103. Fallon, supra note 81, at 1271. 
than weighted balancing, with the scales tipped slightly to favor the protected right. 104

Professor Bhagwat finds similar variation in the Court's application of intermediate scrutiny. "In certain areas," such as commercial speech and regulation of charitable solicitation, "the Court has been extremely speech protective, consistently upholding claims against even quite powerful governmental regulatory interests." 105 On the other hand, "in the area of regulating sexually oriented businesses, the Court . . . has been extraordinarily consistent in rejecting constitutional claims . . ."106 The Court has also been unreceptive to content-neutral regulation of symbolic conduct. ${ }^{107}$ In fact, he concludes, "[t]he pattern of cases is so clear in these two areas of law that one could make a convincing case that the Court has in fact adopted a categorical balancing approach in both areas and resolved the balance against speech claims."108

These diverse applications of the same doctrinal formulae raise the specter of yet another analogy to the regulation of first-order risks. Fallon concludes that "individual Justices tend to vary their applications of strict scrutiny based on their personal assessments of the importance of the right in question." 109 If true, this assertion suggests that cultural cognition is as much a force in doctrinal formation as are precautionary and cost-benefit principles. Put differently, perhaps some quantity of constitutional doctrine develops as a result of the Justices' individual worldviews and cultural commitments. But even so, that strikes us as simply another way of saying that the creation and application of doctrinal tests is a function of the Justices' perceptions of risk and their attempts to regulate that risk in constitutional adjudication.

\section{IMPLICATIONS AND AN AGENDA FOR FUTURE RESEARCH}

As developed in Part II, we agree with Professor Vermeule that risk-based concepts and theories can be applied helpfully to much of what goes on in constitutional design and interpretation. Additionally, building on his ideas, we have argued that the creation and application of judicial doctrine through decision rules is a form of risk regulation-whether or not the Justices consciously

104. Id.

105. Bhagwat, supra note 87 , at 816 .

106. Id. at 817.

107. Id.

108. Id.

109. Fallon, supra note 81 , at 1271. 
understand it to be-and likewise can be studied profitably as such. There are a number of important implications that these insights have for constitutional law generally, and several questions that they raise, as well. In this Part, we will discuss the implications and flag the questions that they raise in hopes of treating them more comprehensively in future work.

As an initial matter, there are two obvious payoffs for the doctrine-as-risk-regulation model. First, it allows the circumstance of decision rules creation to be reframed as an ongoing process rather than a one-time event. In addition, the risk regulation model provides a yardstick with which commentators can measure the efficacy of existing doctrine in the optimal implementation of constitutional principles.

But we think that there are less obvious implications as well. A risk regulation model of doctrine has some explanatory power for aspects of constitutional law that are commonly critiqued: (1) that the Court often protects some rights-even unenumerated oneswhile underenforcing other rights explicitly mentioned in the Constitution; (2) that constitutional doctrine is too formulaic and complex, which undermines the legitimacy of judicial decisions; and (3) that the Court often inconsistently applies its own decision rules without acknowledging that it is deviating from the rules previously laid down. Critics frequently ascribe "politics" as the reason for these alleged deficiencies. We argue that changing perceptions of risk might furnish an alternative explanation.

Taking the doctrine-as-risk-regulation model seriously, however, raises important questions that merit further investigation. We raise three in this section, some of which we hope to examine further in future work. First, should we trust judicial perceptions of and responses to risk? Second, what influences risk assessment among judges, and are those influences (and resulting assessments) normatively defensible? Third, what is the connection-if anybetween judicial risk assessment and attempts to regulate perceived risks through verbal formulae such as those the Court uses in its doctrine?

\section{A. Implications}

\section{Decision Rule Choice is a Process, Not Event}

Though we have alluded to this point before in our previous work, ${ }^{110}$ it bears emphasizing here that the creation and 
maintenance of doctrinal rules is an ongoing process. 111 The Court often adjusts doctrine over time in response to adaptive behavior by officials, additional information, or changes in circumstances.112 Suzanna Sherry recently argued that the Justices' evolving understanding of the facts on the ground can cause the Court to shift its doctrinal rules, sometimes without explicit acknowledgement by the Court.113 The persistence of Court-created AEDs, moreover, suggests that doctrine creation involves a feedback loop. The Court creates a decision rule, then adjusts it over time as circumstances dictate. ${ }^{114}$ In most cases the catalyst for the adjustment is an altered perception of the danger to a particular constitutional principle. ${ }^{115}$

Doctrine therefore, is adaptive; it changes in response to changes in circumstances or, as we have described it here, in response to judicial perceptions of risk. ${ }^{116}$ As Professor Fallon and others have demonstrated, for example, strict scrutiny did not emerge fully formed from William Brennan's skull. Rather, it evolved over time as the Court struggled for a response to particular types of constitutional risk. ${ }^{117}$ As Fallon usefully reminds us, even a Court's application of the same decision rules can vary with context.118 This

serve as a reminder that doctrinal formation is not a static, one-step process, but rather is dynamic and ongoing.").

111. Cf. Tushnet, supra note 19 , at 124 :

There is a long-standing scholarly tradition arguing that, as cases accumulate, courts are driven to move from standards to rules. Experience accumulates, and judges get familiar with some generic features of situations they repeatedly confront. They become increasingly confident that they can devise rules that capture so many of the normatively relevant features of those situations that the benefits of ex ante guidance from rules come to outweigh the benefits of applying standards after the event.

112. Denning \& Kent, Anti-Evasion Doctrines, supra note 6, at 1814-15, 1827-28.

113. Suzanna Sherry, Foundational Facts and Doctrinal Change, 2011 U. ILL. L. REV. 145, 146-47.

114. Denning \& Kent, Anti-Evasion Doctrines, supra note 6, at 1815.

115. See id. (noting that the Court revises and supplements its decision rules "based on risk considerations that subsequently arise").

116. See Tushnet, supra note 19, at 125 (observing that a "rules/exceptions/exceptions approach is actually quite standard" in constitutional law).

117. Fallon, supra note 81 ; see also Stephen A. Siegel, The Origin of the Compelling State Interest Test and Strict Scrutiny, 48 AM. J. LEGAL HIST. 355 (2006) (describing the evolution of strict scrutiny).

118. Fallon, supra note 81 , at 1271. 
gives doctrine, and constitutional law generally, a kind of fluidity that means very few questions are settled for all time. However disconcerting this lack of permanence may seem at first blush, there may nonetheless be ameliorative effects-i.e., saving the Court from what might be called judicial sclerosis that can stunt the law's growth. ${ }^{119}$

\section{Furnishes a Metric for Evaluating Doctrinal Rules}

Another feature of the risk regulation model of doctrine is that it provides a frame for debates about how the Court should "regulate" with regard to a particular constitutional principle. As advocates of cost-benefit analyses debate advocates of precautionary principles over the proper regulatory response to various first-order risks, advocates of different doctrinal rules can debate in similar fashion the proper judicial response to second-order risks. Although arguments that this or that doctrinal rule over- or under-enforces a particular constitutional principle are common fare in constitutional scholarship, ${ }^{120}$ the risk regulation model strikes us as a way to bring questions of appropriate enforcement into sharper focus. In addition, the model furnishes a yardstick with which one might measure the efficacy of particular decision rules against the appropriate standard, wherever one ends up locating it.

\section{The Model's Explanatory Power}

In addition to illuminating the process of decision rule creation and providing a metric for decision rule evaluation, we think the doctrine-as-risk-regulation model offers some less obvious (but no less important) benefits. In this subsection, we describe a few additional ways to cash out the risk regulation model.

Nearly all critiques of constitutional law frequently contain one or more of the following complaints. First, commentators criticize the Court for creating a sort of rights caste system that recognizes and vigorously enforces some rights - even those lacking specific mention in the Constitution-while providing minimal protection for others. For example, scholars decry the Court's relative lack of interest in

119. For two different arguments that the perpetually unsettled nature of many constitutional questions is a beneficial feature of our system, see generally LoUIS Michael SEIDMAN, OUR UNSETTLED CONSTITUTION: A NEW DEFENSE of CONSTITUTIONALISM AND JUdiCIAL REVIEW (2001); Glenn Harlan Reynolds, Chaos and the Court, 91 CoLUM. L. REV. 110 (1991).

120. See generally Sager, supra note 22; David A. Strauss, The Ubiquity of Prophylactic Rules, 55 U. CHI. L. REV. 190 (1988). 
protecting "mere" economic rights as opposed to "civil" liberties involving procreation and contraception. ${ }^{121}$ Second, constitutional law is criticized as being too laden with a complex and confusing skein of doctrinal formulae that transfers power from the sovereign People to the Court charged with maintaining and applying those rules. ${ }^{122}$ Doctrine creates distance between the document and the People, thus robbing the Court's decisions of legitimacy that they might have if that distance were reduced. Finally, the Court is often charged with inconsistency in the application of the decision rules that it does create, producing outcomes different than prior application of those rules would suggest. The Court will do this, moreover, without explicit acknowledgment that it is applying the rules in different ways or that it has created a different standard of review. ${ }^{123}$

Some of these same critics then put the inconsistencies and changes in direction down to "politics," meaning that changes in doctrine or the Court's agenda are driven by the partisan or ideological preferences of the Justices. ${ }^{124}$ One recent critic alleged that the Court's decisions were so driven by the Justices' ideological preferences that it had lost its authority to be considered a court of law. ${ }^{125}$ This extreme cynicism is certainly not something the Justices themselves admit, ${ }^{126}$ suggesting that they are liars, that they suffer

121. See, e.g., RICHARD EPSTEIN, SUPREME NEGLECT: How to REVIVE Constitutional Protection for Private Property (2008); James W. Ely, Jr., Whatever Happened to the Contract Clause?, 4 CHARLESTON L. REV. 371 (2010); Robert G. McCloskey, Economic Due Process and the Supreme Court: An Exhumation and Reburial, 1962 SUP. CT. REV. 34.

122. See, e.g., Akhil Reed Amar, The Supreme Court, 1999 Term-Foreword: The Document and the Doctrine, 114 HARV. L. REV. 26 (2000); Nagel, supra note 4.

123. See, e.g., Gerald Gunther, The Supreme Court, 1971 Term-Foreword: In Search of Evolving Doctrine on a Changing Court: A Model for a Newer Equal Protection, 86 HARV. L. REV. 1, 12 (1972) (discussing the emergence of a standard of review producing "equal protection bite without 'strict scrutiny" without explicit acknowledgement that a new standard of review was employed); Calvin Massey, The New Formalism: Requiem for Tiered Scrutiny?, 6 U. PA. J. CoNST. L. 945, 946 (2004) (noting that results in Grutter and Lawrence were different than the standards of review purportedly applied by the Court might otherwise suggest).

124. See, e.g., JefFrey A. SEgal \& HAROLD J. SPAETH, THE SUPREME CourT AND THE ATTITUDINAL MODEL REVISITED (2002); compare id., with Richard A. Posner, The Supreme Court, 2004 Term-Foreword: A Political Court, 119 HARV. L. REV. 31, 39 (2005) (arguing that constitutional courts are "political courts" but denying that "political" and "partisan" are necessarily synonymous).

125. ERIC J. Segall, Supreme Myths: Why the Supreme Court is Not a COURT AND WHY ITS JUSTICES ARE NOT JUDGES (2012).

126. See, e.g., Jeffrey Toobin, Without a Paddle, THE NEW YoRkER, Sept. 27, 
from collective false consciousness, or that a more charitable explanation exists.

Not being overly cynical ourselves, ${ }^{127}$ we suggest that viewing changes in agenda and doctrine through the lens of risk regulation provides an alternative explanation for the Court's (and individual Justices') behavior over time. First, we will look at changes in the Court's agenda generally, then examine changes in doctrine, and at an even more granular level, look at differences in application of the same decision rules. In each case, we argue, shifts can reflect changes in perceived risk that produce a judicial reaction. (As we made clear earlier, however, we do not claim that ideology plays no role in risk perception. ${ }^{128}$ )

\section{a. Explains Changes in Court's Agenda}

Our first claim is that changes in perceptions of risk can explain shifts in the Court's agenda. The early Marshall Court, for example, viewed states as dangerous rivals to the national polity established by the Constitution, and many of its decisions accordingly imposed limits on state power. ${ }^{129}$ By the time of Marshall's death, however, new Justices with different perspectives on the threat (or lack thereof) posed by state power began to limit Marshall's early

2010, at 34, 41. Toobin's article quotes Justice Stephen Breyer as saying:

There is a tremendous temptation for journalists, for readers, and the average person who thinks about the Court, particularly today, to think these are a group of junior-league politicians, and what they are doing is deciding things on a political basis. That, I think, plays virtually no role in what we do at the Court.

Id. For the Breyer quotation and similar denials that the Court ought to decide according to political predilections of its members from Supreme Court nominees, see Todd E. Pettys, Judicial Discretion in Constitutional Cases, 26 J.L. \& PoL. 123 (2011).

127. Denning \& Kent, Anti-Anti-Evasion, supra note 12, at 416 (looking for explanations for anti-anti-evasion other than "cynicism or tautology").

128. Supra notes $45-48$ and accompanying text.

129. See, e.g., David P. CuRRIE, The Constitution IN the Supreme CourT: THE FIRST HUNDRED YEARS, 1789-1888, at 62 (1985) (describing the early Marshall Court as "a time of vigorous affirmation of national authority and of vigorous enforcement of constitutional limitations on the states"); GEORGE L. HASKINS \& HERBERT A. JOHNSON, 2 HistoRY OF THE SUPREME COURT OF THE UNITED STATES: FOUNDATIONS OF POWER: JOHN MARSHALL, 1801-15, at 15 (1981) ("Not only were the advocates of States' rights vociferous and powerful, but large sections of the inland populace were opposed to centralized government in any form ...."). 
decisions restricting that power and, in fact, "managed to alter constitutional directions without tearing apart the fabric of the Marshall Court heritage."130

Perhaps the most dramatic shift occurred in the mid-1930s-a century after Taney inherited the center chair-when the Court relinquished its dual role as (1) referee of the boundary between state and federal power (and concomitant guarantor of some quantum of exclusive state power) and (2) the last word on the propriety of state regulation of private economic relationships. ${ }^{131} \mathrm{In}$ the famous Carolene Products footnote, Chief Justice Stone expressed confidence in the ability of political safeguards to prevent overreaching in most cases, the exceptions being where a provision of the Bill of Rights was invoked; where racial, religious or other "discrete and insular" minorities were affected; or where obstructions existed to the operation of "those political processes which can ordinarily be expected to bring about repeal of undesirable legislation." 132 In so doing, observed Professor Currie, "Stone established the Court's agenda for the next fifty years." 133 Professor Powe writes that the footnote closed "[1]engthy chapters of American constitutional history" in favor of a "more aggressive concern for civil liberties and civil rights." 134

But if in carrying out this new agenda, "[t]he Warren Court completed the eradication of federalism, once a cherished and innovative part of the American constitutional order,"135 the

130. Gunther, supra note 123, at 5; see also CURRIE, supra note 129, at 62 (arguing that between 1820 and Marshall's death in 1835 "[t]he Court increasingly refused to extend the limits it had found imposed on the states, and it increasingly revealed divisions as Marshall's longtime colleagues were gradually replaced by men of a new generation"); CARL B. SWISHER, V HISTORY OF THE SUPREME COURT OF THE UNITED STATES: THE TANEY PERIOD, 1836-64, at 7 (1974) ("Readjustments were in the offing in the relations between the federal government and the states, between the states and private economic interests, within the realm of money and banking, and between the North and the South on issues of race relations.").

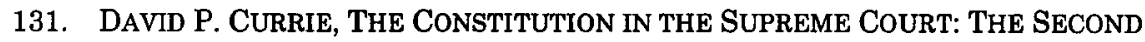
CENTURY, 1888-1986, at 245 (1990) ("Amid the thunder of the great economic controversies that destroyed economic due process, the contract clause, and the concept of limited federal power, the Supreme Court of the 1930s quietly began to work on the agenda of the future: criminal procedure, civil rights, and civil liberties.").

132. United States v. Carolene Prods. Co., 304 U.S. 144, 152-53 n.4 (1938).

133. CURRIE, supra note 131, at 244.

134. LuCas A. Powe, JR., The Supreme Court and the American Elite: 1789-2008, at 216 (2009).

135. Lucas A. Powe, JR., The Warren Court and American Politics 494 (2000). 
Rehnquist Court demonstrated that few things in constitutional law are ever settled for all time. No sooner had Justice Blackmun's opinion in Garcia v. San Antonio Metropolitan Transit Authority136 driven a stake through the heart of judicially enforced federalism, than Justice Rehnquist's prediction that federalism would "in time again command the support of a majority of this Court" bore fruit. 137 In a number of areas-the Commerce Clause, ${ }^{138}$ sovereign immunity, ${ }^{139}$ commandeering ${ }^{140}$ - the Rehnquist Court reasserted its role in policing the boundaries between state and federal power. As a result, in the words of Justice O'Connor, maintenance of "the remaining essentials of state sovereignty" was not entirely left to Congress's "underdeveloped capacity for self-restraint."141

For us, these shifts can be explained as a rational response to the Court's recognition that it cannot do everything. ${ }^{142}$ It must triage issues, weighing carefully which cases will receive its attention, and which can be left to the lower courts or, perhaps, to other branches or levels of government. This requires more than a general feel for the limits of the institution's power. Even where it feels competent to intervene, we think the issues the Court takes up and how it decides them implies some judgment about risk. To borrow from Nash's framework again, the decision to decide ${ }^{143}$ suggests that the Court has, at least, concluded that (1) there is risk, and (2) "the showing of risk [is] sufficient to justify [judicial] action" of some sort. ${ }^{144}$

136. 469 U.S. 528 (1985) (overruling Nat'l League of Cities v. Usery, 426 .U.S. 833 (1976)).

137. Id. at 580 (Rehnquist, J., dissenting).

138. See, e.g., United States v. Morrison, 529 U.S. 598 (2000); United States v. Lopez, 514 U.S. 549 (1995).

139. See, e.g., Alden v. Maine, 527 U.S. 706 (1999); Seminole Tribe v. Florida, 517 U.S. 44 (1996).

140. See, e.g., Printz v. United States, 521 U.S. 898 (1997); New York v. United States, 505 U.S. 144 (1992).

141. Garcia, 469 U.S. at 588 (O'Connor, J., dissenting). For various perspectives on Rehnquist Court federalism, see THE REHNQUIST LEGACY 187-298 (Craig M. Bradley ed., 2005).

142. Cf. Andrew B. Coan, Judicial Capacity and the Substance of Constitutional Law, 122 YALE L.J. 422, 424 (2012) ("[C]ourts can decide only a small fraction of the constitutional issues generated by the American government.").

143. See, e.g., H.W. PERry, JR., Deciding to Decide: AgEnda SETTING IN THE UNITED STATES SUPREME COURT (1991).

144. Nash, supra note 19 , at 192. 


\section{b. Explains Inter-Doctrinal Variety}

Of course, not all risks are the same. Even if judicial doctrine can be understood as a form of risk regulation, there is no reason to expect that either the Justices' perceptions of the magnitude of risk or the Court's response to it will be generic. In this vein, Professor Vermeule stresses that the mature position-i.e., the response that aims for optimal enforcement of a constitutional principle-will differ for risks depending on a number of variables. ${ }^{145}$ Consider again the significance of the Court's use of strict scrutiny as contrasted with the classic form ${ }^{146}$ of rational basis review in equal protection cases. The use of strict scrutiny in racial classification cases suggests a judicial perception that the use of race in conferring benefits or imposing burdens on individuals poses such a risk of harm to the constitutional principle of equality that it will be permitted only after satisfying the Court, first, that very good reasons exist for its use and, second, that those reasons cannot be achieved without it. ${ }^{147}$

Other classifications, by contrast, are not perceived as posing such a risk and are therefore reviewed using deferential decision rules such as rational basis. In Nordlinger $v$. Hahn, ${ }^{148}$ for example, the Court upheld California's Proposition 13, which imposed limits on property tax rates and the degree to which those rates could rise year after year. These limits however, were "subject to the exception that new construction or a change of ownership trigger[ed] a

145. VERMEULE, supra note 16 , at 17.

146. We use the term "classic form" to refer to the traditional, almost completely deferential form of scrutiny, as opposed to rational basis with "bite." See infra notes 167-77 and accompanying text.

147. See, e.g., Fisher v. Univ. of Texas, 133 S. Ct. 2411, 2418-19 (2013):

Distinctions between citizens solely because of their ancestry are by their very nature odious to a free people, and therefore are contrary to our traditions and hence constitutionally suspect.

...

To implement these canons, judicial review must begin from the position that any official action that treats a person differently on account of his race or ethnic origin is inherently suspect. Strict scrutiny is a searching examination, and it is the government that bears the burden to prove that the reasons for any [racial] classification [are] clearly identified and unquestionably legitimate.

Id. (internal quotations and citations omitted).

148. 505 U.S. 1 (1992). 
reassessment up to current appraised value."149 Thus, "[r]eal property [was] assessed at values related to the value of the property at the time it is acquired by the taxpayer rather than to the value it ha[d] in the current real estate market."150 Plaintiffs challenged Proposition 13 on the ground that it discriminated against new purchasers in favor of existing residents of neighborhoods arbitrarily. 151 Because the classification was not a "suspect" onemeaning that it did not "jeopardize] the exercise of a fundamental right or categorize[ on the basis of an inherently suspect characteristic"152 - the Court applied a rational basis test. In this version ${ }^{153}$ of its rational basis test, moreover, the Court presumed the existence of a legitimate interest, even hypothesizing possible reasons for the distinctive treatment regardless of whether those were the actual ones invoked by the state, and concluded that Proposition 13 was defensible under any one of those reasons. ${ }^{154}$

Justice Blackmun closed his majority opinion in Nordlinger with an explanation of the Court's deferential attitude towards the state, despite the possible unfairness produced by Proposition 13:

Time and again ... this Court has made clear in the rationalbasis context that the "Constitution presumes that, absent some reason to infer antipathy, even improvident decisions will eventually be rectified by the democratic process and that judicial intervention is generally unwarranted no matter how unwisely we may think a political branch has acted." Certainly, California's grand experiment appears to vest benefits in a broad, powerful, and entrenched segment of society, and, as the Court of Appeal surmised, ordinary democratic processes may be unlikely to prompt its reconsideration or repeal. Yet many wise and wellintentioned laws suffer from the same malady. [Proposition 13] is not palpably arbitrary, and we must decline petitioner's request to upset the will of the people of California. ${ }^{155}$

149. Id. at 5.

150. Id.

151. Id. at 7-8.

152. Id. at 10.

153. See infra notes 167-77 and accompanying text.

154. Nordlinger, 505 U.S. at 12-13; see also id. at 15 (noting that "the Equal Protection Clause does not demand for purposes of rational-basis review that a legislature ... actually articulate at any time the purpose or rationale supporting its classification").

155. Id. at 17-18 (quoting Vance v. Bradley, 440 U.S. 93, 97 (1979)) (internal 
Thus, in contrast to the Court's assumption that racial classifications posed risks that were unlikely to be outweighed by any countervailing benefit, the assumption in Nordlinger seems to have been that whatever risks of unfairness or arbitrariness existed were either minimal, were not outweighed by the costs of judicial second-guessing of California's policy judgment, could ultimately be remedied through the political process, or some combination of the three.

Decision rules that implement structural principles likewise vary according to risk perception. Take the dormant Commerce Clause doctrine (DCCD). As one of us has argued, the animating principle behind the DCCD is the prevention of commercial friction among states that might fray the bonds of political union. ${ }^{156}$ The Court has concluded that laws explicitly (or covertly) discriminating against out-of-state commerce pose a particular risk of sparking retaliatory cycles that can produce such friction. For this reason, to be upheld, such laws require proof that protectionism is not motivating the legislation and that the state lacks less discriminatory means to achieve its end-a version of heightened scrutiny, but one different in kind from the strict scrutiny employed in equal protection cases. ${ }^{157}$ By contrast, truly nondiscriminatory state regulations nevertheless alleged to burden commerce are subject to a deferential form of balancing where the challenger must show the burdens "clearly exceed" the benefits flowing from the law or regulation. ${ }^{158}$ But as the Court has made clear in its judicially-created exceptions to the DCCD, not all discrimination is seen to pose the same risks. Discrimination when the state is acting as a "market participant"159 or that made in favor of a "public entity" are regarded as carrying much less risk than that motivated by pure economic protectionism. 160

citations omitted).

156. Brannon P. Denning, Reconstructing the Dormant Commerce Clause Doctrine, 50 WM. \& MARY L. REV. 417 (2008).

157. Id. at 451. See generally id. at 441-43 (describing the emergence of the antidiscrimination rule).

158. Pike v. Bruce Church, Inc., 397 U.S. 137, 142 (1970).

159. See, e.g., Reeves, Inc. v. Stake, 447 U.S. 429 (1980) (upholding regulation requiring state-owned cement plant to fill orders of in-state residents before filling those from out-of-state residents in time of shortage; held, state is acting as participant in the cement market and may choose with whom it wishes to deal).

160. United Haulers v. Oneida-Herkimer Solid Waste Mgmt. Auth., 550 U.S. 330,343 (2007) ("[W]hen a law favors in-state business over out-of-state competition, rigorous scrutiny is appropriate because the law is often the product of simple economic protectionism. Laws favoring local government, by contrast, may be 
Examples could be multiplied, but the point is simply one that we (and others) have made elsewhere. Because direct enforcement of the Constitution does not often go far to decide cases, decision rules are necessary. ${ }^{161}$ Thus, the oft-complained of "formulaic Constitution" may simply be the price that we pay for having a Court (and a judiciary) that seeks optimal, as opposed to minimal or maximal enforcement of diverse constitutional principles. ${ }^{162}$

The risk regulation model offers further support for both the existence of doctrinal formulae generally and for the diverse forms those formulae take. Risks to constitutional principle are not uniform; judicial enforcement, therefore, should likewise be variegated. As new risks materialize or as official action adapts to old doctrine, perhaps seeking to evade it, 163 new decision rules can emerge. Similarly, as perceptions of risk change, the Court, too, can adapt. Take gender classifications: Until the early 1970s, they were thought to pose little risk to equality principles because of commonly-held assumptions about gender roles. ${ }^{164}$ When those assumptions began to be questioned, the Court first subjected them to rational basis with "bite," 165 then to a newly-created intermediate scrutiny that eliminated the most egregious gender discrimination while preserving classifications intended to aid women. ${ }^{166}$

\section{c. Explains Intra-Doctrinal Inconsistency}

Finally, as the use of rational basis to strike down arbitrary gender classifications demonstrates, the Court has frequently employed standards of review in ways that produce surprising results. Since Gerald Gunther described the emergence of a lessdeferential rational basis review in the early 1970s, it has become a mainstay in the Court's doctrinal repertoire. Consider the use of

directed toward any number of legitimate goals unrelated to protectionism.") (internal quotations and citations omitted).

161. See RoOSEVELT, supra note 2.

162. Denning \& Kent, Anti-Evasion Doctrines, supra note 6, at 1817-26.

163. Id. at $1827-28$.

164. See, e.g., Goesaert v. Cleary, 335 U.S. 464 (1948) (upholding state prohibition on bartending by women).

165. See Gunther, supra note 123, at 18-20 (describing the less deferential form of rational basis used in cases decided by the Court in the 1971 Term).

166. Compare United States v. Virginia, 518 U.S. 515 (1996) (invalidating Virginia Military Institute's male-only admissions policy), with Michael M. v. Superior Court of Sonoma Cnty., 450 U.S. 464 (1981) (concluding that California's statutory rape law was not unconstitutionally discriminatory even though it protected only underage women). 
rational basis review in cases like Department of Agriculture $v$. Moreno, ${ }^{167}$ City of Cleburne v. Cleburne Living Center, ${ }^{168}$ Plyler $v$. Doe, ${ }^{169}$ Romer v. Evans, ${ }^{170}$ and Lawrence v. Texas. ${ }^{171}$ In each case, ostensibly applying a rational basis standard, the Court invalidated the challenged law. The application of the standard, moreover, bore little resemblance to that in cases like Nordlinger $v$. Hahn: The legitimacy of state aims was not presumed, and the Court refused to hypothesize acceptable reasons that would support the classifications or regulation. At the other end of the spectrum, strict scrutiny is not necessarily "fatal in fact," 172 as Gunther once described it. ${ }^{173}$ The Court in Grutter, for example, applied strict scrutiny in a rather deferential manner to the Michigan law school's admissions program. ${ }^{174}$

The emergence of sub rosa standards of review have garnered criticism from commentators who argue such "subterfuge" makes the Court seem unprincipled or dishonest. ${ }^{175}$ While we share some of the frustrations that result from inconsistent doctrinal applications, we think that viewing the Court's doctrine from a risk regulation standpoint helps to explain such inconsistencies and thus, makes them appear more justifiable. Even if it is decided that a particular set of decision rules is generally suited for a set of cases, the risks raised in individual members of that set might appear different in light of concrete facts than they do in the abstract.

167. 413 U.S. 528 (1973) (invalidating legislation restricting eligibility for food stamps to households comprised of related persons).

168. 473 U.S. 432 (1985) (holding unconstitutional requirement that group homes for the mentally disabled, but not other group homes, had to obtain special use permit).

169. 457 U.S. 202 (1982) (striking down Texas law prohibiting undocumented children from enrolling in public school).

170. 517 U.S. 620 (1996) (invalidating Colorado constitutional amendment withdrawing protected class status from gays and lesbians; concluding unconstitutional "animus" motivated passage of amendment).

171. 539 U.S. 558 (2003).

172. Gunther, supra note 123 , at 8 .

173. See, e.g., Fallon, supra note 81 , at 1267 (describing the variations of the decision rules known collectively as "strict scrutiny"); see also Adam Winkler, Fatal in Theory and Strict in Fact: An Empirical Analysis of Strict Scrutiny in the Federal Courts, 59 VAND. L. REv. 793 (2006).

174. See Grutter v. Bollinger, 539 U.S. 306, 327 (2003) (noting that "[c]ontext matters when reviewing race-based governmental action under the Equal Protection Clause" because "[n]ot every decision influenced by race is equally objectionable").

175. See, e.g., Massey, supra note 123; Kermit Roosevelt III, Constitutional Calcification: How the Law Becomes What the Court Does, 91 VA. L. REV. 1649 (2005); Sherry, supra note 113. 
For example, it seems that the Moreno-Plyler-Cleburne-Romer line of cases recognize that the usual rational basis default rulethat political safeguards are sufficient to guard against governmental overreaching-may not apply in cases involving identifiable out groups whose members might not be able to activate the normal safeguards that restrain simple majorities. With such out groups, the risks that some unsavory motivation-call it "animus," prejudice, fear, or what have you-lies behind the classification or legislation is higher than it is when the target is simply, say, recent purchasers of real estate. ${ }^{176}$ Moreover, these out groups may not share the same opportunities for "voice" (i.e., sufficiently meaningful participation in the political process) or "exit" (i.e., the ability freely to accept or reject participation in a given organization, program, or political jurisdiction) that are enjoyed by other groups, ${ }^{177}$ suggesting that they may not be able to adequately employ whatever safeguards the political process normally offers. If one of the goals of doctrinal risk regulation is optimal enforcement of constitutional principle that strives toward a "mature position," then mindless application of decision rules heedless of context would be a foolish consistency indeed. At the very least, adopting a risk regulation model provides a defense against charges that the Court's variations in its application of decision rules is necessarily dishonest or unprincipled.

\section{B. Agenda for Future Research}

If the doctrine-as-risk-regulation model has some purchase, and perhaps even some explanatory power, it raises a number of issues that warrant study. These questions occur both at the wholesale and retail levels. Is there, for example, reason to believe that the Court and its Justices can accurately assess risk, much less regulate it with doctrine? Professor Nash has his doubts. "[C]ourts," he notes, "generally lack sufficient information to conduct meaningful risk analysis," and information is crucial because "[r]isk analysis draws upon empirical evidence."178 Even with access to empirical evidence, there are reasons to wonder whether the right lessons will be drawn

176. Cf. Daniel Farber \& Suzanna Sherry, The Pariah Principle, 13 CONST. COMMENT. 257, 258 (1996) ("This principle, in a nutshell, forbids the government from designating any societal group as untouchable, regardless of whether the group in question is generally entitled to some special degree of judicial protection, like blacks, or to no special protection, like left-handers (or, under current doctrine, homosexuals).").

177. See Ilya Somin, Revitalizing Consent, 23 HARV. J.L. \& PUB. POL'Y 753, 761-62 (2000) (distinguishing "voice" and "exit").

178. Nash, supra note 19 , at 220. 
from it, or whether the evidence will be distorted because Justices no less than the rest of us are subject to a host of cognitive biases that can affect our perception of risk. 179 If that is indeed the case, are there ways to de-bias judicial thinking to leave the Justices less open to cognitive error when considering whether (and, if so, to what extent) risk exists to constitutional principle?180

Moreover, if part of the Court's risk assessment includes a judgment that particular political risks warrant judicial solutions, what factors contribute to that judgment?181 In earlier work, we have hypothesized that the decision whether or not the Court creates an anti-evasion doctrine turns on evidence that political safeguards are sufficiently robust to protect against constitutional overreaching. ${ }^{182}$ If this is true for supplementary decision rules like anti-evasion doctrines, might it also be true when decision rules are initially created by the Court? In other words, the Court's choice of one (more or less deferential) decision rule over another might be a proxy for the Court's view of the adequacy of political safeguards for that particular constitutional principle. ${ }^{183}$

Even if one thinks the Court can use doctrine to perform this risk regulation function, one might ask whether it has chosen the appropriate vehicle in particular areas. As we have demonstrated, a good deal of the Court's doctrine reflects precautionary concerns. But Professor Vermeule notes that precautionary principles are vulnerable to a number of objections. He identifies futility, jeopardy, and perversity arguments, as well as arguments for ex post as

179. See generally Daniel KaHneman, Thinking FAST AND Slow (2011). For evidence that judges are susceptible to cognitive biases described by Kahneman, see, for example, Chris Guthrie, et al., Inside the Judicial Mind, 86 CORNELL L. REV. 777 (2001) (conducting empirical study of federal magistrate judges and concluding that judges are as susceptible as other decisionmakers to certain cognitive biases). See also Alexander I. Platt, Debiasing Statutory Interpretation, 39 OHIO N.U. L. REV. $275,291-92$ (2012) (discussing various studies that indicate judges are susceptible to cognitive biases).

180. Cf. Paul M. Secunda, Cognitive Iliberalism and Institutional Debiasing Strategies, 49 SAN DIEGO L. REV. 373, 387-406 (2012) (discussing possible debiasing mechanisms, ranging from opinion writing techniques to institutional reform, to counter "culturally motivated cognition and the related phenomenon of cognitive illiberalism in labor and employment law cases").

181. Cf. Denning \& Kent, Anti-Anti-Evasion, supra note 12 , at $415-31$ (hypothesizing what makes the Court unwilling to create anti-evasion doctrines in cases where it might have done so).

182. Id. at $422-31$.

183. We are currently working on another paper taking this position. Brannon P. Denning \& Michael B. Kent, Jr., A Political Safeguards Theory of Decision Rules (unpublished work-in-progress). 
opposed to ex ante remedies, as responses to calls for precautionary principles.

"Futility arguments" are those in which "the opponent argues that a given precautionary principle will fail to attain its ends." 184 "Jeopardy arguments" hold "that a given precaution will produce net costs in light of countervailing risks on other margins." 185 That is, "the opponent points to a distinct countervailing risk whose expected costs will be increased by the precaution." 186 on the other hand, "perversity arguments" make the case that "a given precaution will prove self-defeating because of countervailing risks on the same margin-in other words, because it actually exacerbates the very risk the precaution attempts to prevent." 187 Finally, precautionary principles may be met by the objection that stringent ex ante remedies are unnecessary when ex post remedies can be "applied case-by-case, after the relevant risk has actually materialized." 188

184. VERMEULE, supra note 16 , at 54.

185. Id.

186. Id. at 58 (footnote omitted).

187. Id. at 54 .

188. Id. Vermeule offers several retail-level, doctrinal examples of each response to arguments for precautionary principles. For example, critics can employ the futility argument against precautionary principles in First Amendment jurisprudence-whereby judges commit to providing strong free speech protections in times of crisis-and claim that they "will systematically tend to prove futile when they would prevent government from taking action against apparently dangerous threats." Id. at 57. Precautionary free speech principles could also be described as perverse because they may end up undermining the very idea of free speech "by tolerating political speech and participation by groups who would repeal liberal protections if they came to power." Id. at 69. For a thoughtful examination of this problem in a comparative perspective, see Samuel Issacharoff, Fragile Democracies, 120 HARV. L. REV. 1405 (2007).

The rule of reasonable doubt is vulnerable to the jeopardy objection, argues Vermeule, because focusing exclusively on false positives-convictions of innocent persons-"overlook[s] the countervailing risk of false negatives." VERMEULE, supra note 16 , at 61 . Releasing guilty persons raises the risk they will commit future crimes thus "depriv[ing] third-party innocents of their liberty," meaning that "the liberty of innocents appears on both sides of the balance...." Id. (footnotes omitted).

Lastly, the strict rule against state taxation of federal instrumentalities was, at one point, expanded to include "private parties who do business with the federal government," $i d$. at 73 , thus creating a powerful ex ante restraint on state taxing power. As Vermeule explains, "the point of this doctrine was to create a precautionary buffer to protect the freedom of otherwise valid federal operations." Id. The Court later abandoned this strict approach, adopting instead Justice Holmes's position that "ex post, case-by-case assessment of the destructive effect of state taxation on federal contractors would be enough to protect vital federal interests, without overprotecting those interests to such a degree as to squash the legitimate 
Vermeule suggests that those proposing precautionary principles as the proper vehicles for regulating political risk-a group that surely includes many judges and scholars-focus unduly on "fat tail" risks without recognizing that " $[t]$ he very constitutional structures that rulemakers set up to safeguard against remote but extremely damaging possibilities may themselves create a remote chance of an exceedingly harmful outcome."189 In extreme circumstances, judges may "display a pathological fear of succumbing to pathological fear, a kind of phobophobia" and "prove pathologically unwilling to bend or break the rules ... even when such exceptions are socially desirable, all things considered." 190 That rigidity can, in turn, undermine the principle they were seeking to protect in the long run.191

As a possible antidote to such overestimation or one-sided calculation of risk, Vermeule recommends the mature position, which seeks optimal (rather than maximal) protections. ${ }^{192}$ In a world where there are more judicial Herberts than Herculeses, ${ }^{193}$ however, one might question whether judges can ever rise above their own cognitive limitations and accurately establish the mature position. Such doubts may lead someone to recommend something like Thayer's rule of clear mistake in most constitutional cases. ${ }^{194}$

Finally, if we're correct that the fundamental issue in decision rule choice is whether or not to defer to other branches of government based on the perceived risk to constitutional principle presented by a particular case or set of cases, then how exactly do the myriad verbal formulae employed by the Court reflect both its perception of and response to risk? ${ }^{195}$ Could these be scrapped in favor of "generic constitutional law,"196 such as the proportionality

taxing power of the states." Id.; see, e.g., United States v. New Mexico, 455 U.S. 720 (1982) (upholding nondiscriminatory state taxes on federal contractors).

189. Id. at 80 .

190. Id. at 83 .

191. Id.

192. Id. at 85 (arguing that "the mature position has an important negative function . . . in the domain of constitutional design and interpretation: it places tradeoffs on the 'viewscreen' and thereby excludes unconstrained demand for 'maximal safety' or 'security' against perceived risks") (footnotes omitted).

193. The reference is to Ronald Dworkin's "lawyer of superhuman skill, learning, patience and acumen" as compared with the more pedestrian "Herbert." RONALD DWORKIN, TAKING RIGHTS SERIOUSLY 105, 125 (1977).

194. James Bradley Thayer, The Origin and Scope of the American Doctrine of Constitutional Law, 7 HARV. L. REV. 129, 144 (1893) (articulating his rule of clear mistake).

195. On the origins of judicial scrutiny, see G. Edward White, Historicizing Judicial Scrutiny, 57 S.C. L. REV. 1 (2005).

196. David S. Law, Generic Constitutional Law, 89 MINN. L. REv. 652 (2005). 
principle employed by constitutional courts around the world? 197 Or do the choice of words and phrases have some independent value that corresponds to differing levels of risk as perceived by the Court, as we suggest above? Might a focus on the particular risks themselves (as opposed to the verbal formulations of the standards of review) clarify what risks the Court is seeking to regulate and enable it to better fit standards to risks, rather than the other way around?

\section{CONCLUSION}

Decision rules created by courts to implement constitutional principles-what we have called "judicial doctrine"-can be understood as an example of second-order political risk regulation. Regarding the creation and application of judicial doctrine as a form of risk regulation has considerable payoff for the study of constitutional law. First, it contributes to the understanding of doctrine as a fluid, not static, body of law. Second, it provides a metric by which the success or failure of doctrine can be measured. Adopting the risk regulation model also provides some explanation for aspects of constitutional law that bedevil observers: the tendency of the Court to shift its agenda over time; the variety and complexity of constitutional doctrine generally; and the Court's occasional inconsistency in the application of its decision rules. At the same time, the risk regulation model of doctrine raises questions, specifically about the capacity of Justices accurately to assess risk and develop decision rules that provide optimal, as opposed to maximal or minimal protection, for constitutional principle generally, as well as in specific areas of constitutional law.

197. See, e.g., Alec Stone Sweet \& Jud Matthews, Proportionality Balancing and Global Constitutionalism, 47 COLUM. J. TRANSNAT'L L. 72 (2008). 